Studia Anglica Posnaniensia 52(3), 2017

doi: 10.1515/stap-2017-0015

\title{
LAURENCE HOUSMAN'S THE MOON-FLOWER AND VICTORIAN MYSTIC IMAGINATION
}

\author{
EMILIA WIELICZKO-PAPROTA*
}

University of Gdańsk

\begin{abstract}
The paper explores the theme of mysticism in Laurence Housman's fairy tale "The Moon-Flower" (1895). It presents the main assumptions of a Victorian inner journey toward a mystical union and analyses symbols which construct the inner landscape which undergoes a mystic transformation. The author attempts to show the metamorphosis of the fairy tale's main characters and identify its roots in both fairy tale and religious traditions. It is argued that Victorian fairy tales reflect a credible quintessence of the universe. The retold tales of an archetypical quest full of powerful symbols uncover the sublime world hidden under the dull reality. Hence, "The Moon-Flower" is believed to tell the story of inner transformation and open the doors to the myriad stories which were told before and create countless possibilities of interpretation.

Keywords: mysticism; fairy tale; Victorian mystical imagination; archetypical symbol; inner landscape

Holbrook Jackson in The Eighteen Nineties stressed the importance of the mysticism revival in the social life of Victorian England which was stricken by decadence: "The decadence was a form of soul-sickness, and the only cure for the disease was mysticism" (1913: 132). The rising importance of mysticism may be interpreted differently as a response to a developing materialism and a symbol of a crisis of faith (Oppenheim 1985: 61), a symbol of an unstable society which seeks alternative ways of life (Hughes 1958: 33), or a part of fashionable modern trends fascinated with the occult and the Orient (Owen 2004: 20). J.W. Buckham sees the renewed fascination as a revolt against the dominance of science, absolutism, and dogmatism:
\end{abstract}

Faculty of Languages, Institute of Polish Language and Literature, University of Gdańsk, ul. Wita Stwosza 55, 80-308 Gdańsk, Poland; email: emiliawieliczko@wp.pl 


\begin{abstract}
Our age is weary of a science that resolves the universe into the mere play and product of unintelligent forces, of a materialism that seeks only utilitarian or hedonistic ends, of a philosophy that sinks spiritual values in intellectual formulas, and of a theology that goes on asserting ancient dogmas without revitalizing them or relating them to new truth. Mind and heart are calling for something deeper.
\end{abstract}

(Buckham 1915: 22)

For F. B. Wilson (1908: 17) the "mystic turn" was an inevitable consequence of the evolution of a progressive mind. The "active man" involved in the conquest of the world would evaluate "his source of power" and constantly ask "questions concerning the soul" (Wilson 1908: 18). The need for true knowledge is natural in human history and mysticism was its leading path. Mysticism was perceived as a particular state of mind, a transcendental feeling, an intimate experience which opens the doors to a spiritual realm. "The mystic is somewhat in the position of the man who, in a world of blind men, has suddenly been granted sight" (Spurgeon 1913: 6). The only power by which people could participate in the divine state of mystic illumination was symbolic imagination. A symbol, under imaginative supervision, united the sublime and the sensuous, the earthly and the divine, the mortal and the immortal. In accordance with the Victorian knowledge of the human Psyche, the doors to mystic enlightenment or the source of symbolic illumination were hidden in the human subconsciousness. The new, inward approach to mysticism required a new language to express the mystic experience, one which would not refer to emotions but to the process of crossing the psychological realm. It was in fantasy fiction that symbolic imagination fulfilled its quest of achieving the mystical union; it represented the language of free imagination, unconstrained rules, and sensitive perceptivity. The interpretation of Laurence Housman's fairy tale "The Moon-Flower" (1895) attempts to familiarise the reader with late Victorian fairy tales related to religious philosophy and mystical imagination. Laurence Housman, being a prolific author of fairy tales, plays, and poems, many of which possess mystic undertones, was one of the most innovative artists of the language of fantasy literature. The main objective of this paper is to show the characteristic features of mystic fairy tales: the theme itself, the innerness of the setting, the transformative philosophy, and the complex symbolism.

In "The Moon-Flower" the Moon Princess dwells on the moon, and she loses her pearl which falls down to the earth. The Princess descends to the earth to seek her pearl out. There she encounters a red gnome who is known in the moon realm as a merchant of earthly jewels. Led by curiosity, the Moon Princess follows the encountered seller to his house and becomes his prisoner until she marries him. At the same time, the Prince of the earthly kingdom loses his way in the woods and discovers the red gnome's house. The Moon Princess and the Prince fall in love 
with each other and devise an escape plan. Unable to fulfil it, they are caught by the gnome who transforms the Princess into a moon flower rooted in the ground. Watered by the love of the Prince the moon flower gives birth to a quicksilver child which jumps out from beneath its roots. The child saves both lovers and helps them to ascend to the moon. The three Housman's characters: the Moon Princess, the Prince, and the underground-dwelling gnome/mole reflect the Victorian faith in a trifold structure of man: "There is an earthly man and the natural man; but there is above all a spiritual man" (Stanley 1879: 207). The co-existing "selves" function simultaneously but not harmoniously until the process of a mystical unification is accomplished. The spirit (the Princess) has to be united with the soul (the Prince) as well as with the body (gnome/mole), which is the organ of the soul. The soul in Victorian mysticism is identified with the "ego", the part of the self which is encumbered with choice, always divided between the divine and the material: "He may rise to the spiritual man, or he may sink to the carnal man" (Inge 1947: 35). Hence, the Prince in "The Moon-Flower" is a future king without a kingdom, a possessor of a heritage without the knowledge of its meaning. As long as he is suspended and unaware of his destiny, the Princess' consciousness is disturbed and distorted by a fascination with earthly gemstones which symbolize earthly beauty. Housman presents the relation between the soul and the spirit in the manner of a divine syzygy. They are not polarities; they trigger and reflect each other. This is the issue which the Victorians strongly emphasised: the spirit differs from the platonic nous; it is not absolutely impeccable and disconnected. Following the late nineteenth century mystic imagination: "There is an interlacing or marrying between the several planes of consciousness, and ... none of these can be cultivated to the absolute exclusion to the others" (Wilson 1908: 89). W. R. Inge (1947) accentuates the consequences of this theory indicating that the Christian spirit may be defiled as long as the untransformed soul affects its existence. Therefore, it is essential to enlighten the soul and protect the spirit from its material side.

In Housman's fairy tale the unification begins with a journey towards the unknown. The Moon Princess has to descend to the earth to face the dark side of her own passions; the Prince has to go deep into an unknown forest to find the spirit and understand himself. The disappearing pearl which the Princess follows and the running shoe which belongs to the Prince are, in Campbell's language, typical "blunders". They beget the mystic quest, open the gate to destiny, and introduce the protagonists to unknown or previously suppressed desires (Campbell 1949: 42). The encountered beasts, impossible tasks, and labyrinths of hostile forces are the elements of this first stage of the mystic path. In the alchemical unus mundus this level is known as the recognition of the shadow; in Christian mysticism it is the dark night - the trial of determination. The gnome/mole is a symbol of shadow, and it rules the land of the unknown. It reflects the lower self, an element shared with the animal kingdom. For Victorian 
traditionalists the idea that human beings are somehow mentally and morally related to animals was absolutely dreadful. The struggle with disturbing image of the immanent and instinctual beast had a huge impact on nineteenth-century fantasy, and fairy tales are abundant in monsters representing the subconscious (Prickett 1979: 93). In mystical fairy tales “'the black beast,' the passional element of the lower nature must emerge and be dealt with before anything further can be done" (Underhill 1912: 173). Captured by lower forces, the Moon Princess has to awake the Prince/soul to surmount the dark force; the soul has to realise its duty and unite itself with the spiritual plane. The love, recognition, and unification between the spirit and the soul are expressed in a symbolical marriage. However, the conjunction at this stage is not sufficient to escape from the shadow's influence. The restrained earthly element seduces the soul with an image of gemstones and ruins the liberation the very moment the Prince and the Princess may be freed from material imprisonment. In consequence, the Princess is turned into a rooted moon-flower and tied to the earth. The Prince's pain, tears, longing, and regret after the loss are essential elements in the mystical transformation: It is a description of a Christ-like pain, a state of absolute hopelessness and emotional torment which are most vivid and convincing in Victorian descriptions of the mystic path. The final transformation is stressed to be "that process of losing to find, of difficult transcendence through effort and failure" (Underhill 1913: 139). Thus, pain is an indispensable component: "The result of this pain and effort is the introduction of the transmuted self into the state of the Union, or complete harmony with the divine, towards which it had tended from the first" (Underhill 1913: 55). The state of the union comes in the image of a saviour - the quicksilver child which springs from the moon flower's roots. The fact that the child is born from the earth's womb and, in consequence, partly belongs to the mole kingdom may not be underestimated. The last stage of the mystical path is a transmutation of the shadow into the redeemer. This is the last phase of the alchemical unus mundus. Carl Gustav Jung explains it in the following way:

At length the body is compelled to resign itself to, and obey, the union of the two
that are united [soul and spirit]. That is the wondrous transformation of the
Philosophers, of body into spirit, and the latter into body, of which there has been
left us by the sages the saying, Make the fixed volatile and the volatile fixed, and in
this you have your Magistery. Understand this after the following manner: Make the
unyielding body tractable, so that by the excellence of the spirit coming together
with soul it becomes a most stable body ready to endure all trails. (Jung 1970: 481)

The Victorian mystic path represented in "The Moon-Flower" is the inner process which unifies human levels of consciousness. The theme of the hero destined to achieve a mystic union is very popular in Victorian fairy tale writing. It might be, 
as Rodney Engen noticed in Housman's biography (Engen 1983: 26), that fairy tales served as compensation in the difficult times of nineteenth-century religious doubts. A great amount of mystic tales were inspired by the Romantic tradition which regarded the "faery world" as a metaphor for the spiritual realm (Sander 1996: 34). However, late Victorian writers fashioned the idea into their own shape, suitable for the modern mind. In her book about mysticism, Evelyn Underhill mentioned three ways of illustrating the mystic path depending on one's attitude towards the divine: a mystic quest - for those who see it far from the self; a mystic marriage - for those who consider it a personal feeling and a deep desire; and the "Great Work of Spiritual Alchemists" - for those who see the divine as immanent in the world and the self and treat it as a seed which has to be transformed into a blossom (Underhill 1912: 129). The distinctive feature of late Victorian mysticism is that it mostly refers to an immanent shape. Adela Curtis perfectly expressed this changed attitude towards religion by contrasting the ancient Eastern mystical creed "Destroy self-consciousness" with the modern "I came not to destroy but to fulfill" (Curtis 1906: 76). The innate mysticism had a considerable impact on Victorian fairy tales. Not only do they raise the subject of inner transformation (very often referring to alchemical symbolism) but also illustrate the innerness using archetypal landscapes of consciousness. In "The Moon-Flower", three settings which strongly suggest the immanent meaning of the plot are presented: the forest, the house, and the garden.

The forest is one of the symbols widely used in literature and oral tradition as a place of initiation. It is a highly complex symbol, but the main meaning is built around its chaotic features. As H. R. Zimmer stressed, unlike cities and human habitats, the forest is unpredictable, without fixed borders, changeable and mysterious (Zimmer 1993 [1948]: 182). The hidden corners and dark nooks were believed to be inhabited by all kinds of natural forces. The adepts of initiation dispatched to a forest were supposed to face their own fear, to be prepared for adventure, and seek their own destiny among the density of ambiguity. In the forest, the hero can find all kinds of enchantresses' palaces, witches' huts, hidden treasures, or Merlin's castles. This is where he can also kill a beast, fulfil a task, or achieve an aim - all being means by which the transformation may be accomplished. Due to all these enigmatic features the forest becomes a symbol of consciousness. "In its terrifying abyss, full of strange forms and whispering voices, it contains the secret of the soul's adventure" (Zimmer 1993 [1948]: 182). Tales of the inner journey usually start in the same manner, as H. Silberer notices: "There was once a king whose greatest joy was in chase. Once as he was drawn with his companions into the great forest, and was pursuing a fleet stag, he was separated from his followers ..." (Silberer 2003 [1917]: 46). In "The Moon-Flower", the Prince's journey begins with similar words: "Now one day the Prince went out hunting in the forest, and there, having become separated from all his friends, he thoroughly lost his way" 
(Housman 1895: 139). The hunting motif is an essential element in the forest theme. It denotes a change of perception. Anne Rooney in Hunting in Middle English Literature accurately notices that hunting is usually associated with secular activity and worldly vanities (Rooney 1993: 102). The hero enters the forest/consciousness as a person occupied with secular joys and unaware of one's spiritual needs. The separation and the forest's mysterious force lead him to a different level of perception, to divine understanding. The Prince enters the forest without the knowledge of his destiny but, being lost and led by the suddenly enlivened shoe, he finds its centre - a house with a garden and a trapped spirit inside.

The Prince, after an exhausting run through the dense forest, is compared to the house: "He had lost his hat, and his cloak was torn into patterns, and he felt from head to foot like a house all doors and windows" (Housman 1895: 141). However, the house he enters, described several lines further, lacks the prominent character of openness: "Strange little house of green bronze, shut in by a high wall, and showing no windows; and in the middle of the wall was a bronze door shut fast" (Housman 1895: 141). The seclusion of the house is purposely highlighted in this short description. It is a prison-like space without any connection with the outer world. Since the house in general is a symbol of enclosure and protection, it is an extension of the mother archetype and the womb (Stevens 1998: 153). In the spiritual sense, it is the absolute center of consciousness whence human cognitive life starts. It does not come as a surprise though that Housman's house possesses the features of a cave. A cave is a symbolical womb to which one must return in his/her life to be able to be reborn. As Jung states: "Anyone who gets into that cave, that is to say into the cave which everyone has in himself ... will find himself involved in an - at first unconscious process of transformation" (Jung 2015 [1969]: 3643). The womb is suggested by the symbol of the self-covering table. The automatic provision of all necessary nourishment indicates safety and outer protection. The interior intensifies the cavernous character: "All its walls were hung with gold and precious stones, but everywhere was the emptiness and the silence of death" (Housman 1895: 142). The presence of dazzling stones and glittering gold signifies the spiritual transmutation of darkness into light: "Wherever they went, out of the floor before them rose burning jewels that hung hovering over their heads to light them as they passed" (Housman 1895: 151). The centre of our consciousness, despite the imprisoning character, is lined with divine signs of the inevitability of the transformation. Once one is inside there is only one direction to follow - into the deeper self, the garden: "Through the windows he saw deep bowery gardens ..." (Housman 1895: 142).

The garden is a motif excessively used by the Pre-Raphaelites. Suffice to look at some of the paintings in which a woman's silhouette is depicted against a garden background. It is the fascination with medieval art which inspired the Pre- 
Raphaelites to regard the garden as a great symbol of love and spirituality. Housman was closely associated with the Brotherhood and his great interest in the garden symbolism is undoubtedly due to their influence. In his fairy tales the garden is a recurrent theme. Needless to say that for the title page of "The MoonFlower" Housman chose an illustration of the meeting of the Princess and the Prince in the enclosed garden. Medieval gardens are complex in their symbolism. Depending on the context they may symbolise the garden of pleasure or the garden of transcendence. In both meanings, Eros is the main host, which follows the Song of Songs tradition where the lover is compared to an enclosed garden. Frequently, medieval, walled gardens were a contemplative space where one could withdraw from the outer chaos into a paradise-like harmony. In "The Moon-Flower" this orderly character is emphasised and, at the same time, contrasted with the unruly forest in the description of the well-maintained garden: "Everywhere were the traces of gentle handiwork" (Housman 1895: 142). Hence, the harmonious space is a temple of transformation and spirituality where one can feel love for higher existence and admire the divine order of the world. The enclosed garden is a microcosm which unifies all levels of universal and individual existence. It is where space may be understood, but only with transcendental perception: "It is not fixed and invariant like ours. It can be lengthened and shortened, changed and altered; and since it cannot be defined by measurement, we here cannot grasp it with an earthly concept" (Swedenborg 2003 [1763]: 54). The garden opens downwards to the red mole's kingdom and upwards through a pool of still water to the celestial universe. The axis on which the structure is built is a bottomless and vertical well. In medieval culture a fountain bursting with the water of life was an inseparable object of the garden landscape. Housman chose to include the well as it represents human will and the activity of raising the water which, in consequence, illustrates active participation in the transformation. Underground water is a symbol of the unconscious. The act of bringing the water up initiates a healing process. Underground forces brought to the light are cleansed from darkness and unknowing. The "enlightened" waters create a still pool, an undisturbed mirror of the true self and a gate to a divine state.

The three main components of the landscape emphasise the immanence of mysticism. The forest symbolises the mysterious, unfamiliar sphere of ordinary cognition; the house - the centre of the self's emanation; the garden - the place of transformation. The arrangement of space from vast to confined and from earthly closeness to transcendental openness implies a development. The transformation is the leading motif of "The Moon-Flower", as it is the leading motif of fairy tales in general: "The wonder tale and fairy tale are, in essence, transformative narratives on transformations" (Hasse 2008: 982). In mystic fairy tales, the metamorphosis refers to the multifaceted self. However, Laurence Housman ventures further in his 
transformative thought. It is not only a unification and transmutation of the Moon Princess, the Prince, and the gnome; it is the main force pervading the tale just like the Bergsonian elan vital runs through the veins of the macrocosm and the microcosm. The one who triggers the omnipresent motional force is the gnome/red mole/quicksilver child - the typical trickster.

The half-gnome/half-mole is an evil spirit which lives underground; hence, it is associated with the dark powers of an unknown realm. From the underground kingdom and the roots of the moon flower comes the quicksilver child, a transformative force which saves the Princess and the Prince. Quicksilver in alchemy personifies Mercurius. As a metal it is one of the most indefinite substances: solid or liquid and changeable in room temperature. That is why the elusive quicksilver became the symbol of obscure Mercurius - the ambivalent god of death, decomposition, transcendence and "mystic psychic wholeness" (Haeffner 1994: 143). The quicksilver child/Mercurius is versatile; it can change its own appearance as well as it can alter someone else's. It is good and evil, male and female; its typical environment is water, but it can dwell in the realms of air, fire, or earth. It divides all and combines all. Thus, it is the beginning of the alchemical process, the cause of transmutation and, at the same time, its end, the result of the development. In the brothers Grimm fairy tale "The Spirit in the Bottle", a woodcutter releases the "mighty spirit Mercurius" from a bottle (Grimm \& Grimm 2008 [1822]: 484). The spirit threatens to strangle its saviour in revenge for long imprisonment. The woodcutter tricks the spirit and forces Mercurius to slip back into the bottle. Later the protagonist makes Mercurius promise that he will not hurt him if he releases him again. Liberated Mercurius rewards the woodcutter and grants him a life of richness and fulfilment. "Therefore, the wise alchemists knew better than to allow Mercurius to run free in the initial phases of the alchemical process" (Cicchetti 2003: 18). Carl Gustav Jung's fascinating interpretation (Jung 1970: 340) indicates that Mercurius is a natural state of man which can be dangerous if left free without any outer developing force. In "The Moon-Flower" the quicksilver Mercurius at the initial phase of transmutation is represented by the gnome, a very earthly symbol of the self. Despite its evil nature, in the image of gnome we may find a transformative potential.

In nineteenth-century esoteric tradition, the gnome plays a significant role. Rudolf Steiner (1995 [1992]: 120) emphasised that although the gnome is a truly earthly element, it represents the extra-terrestrial force in the Earth. In order not to be unified with the amphibian underworld, the gnome usually occupies itself with the idea of ascending to the upper world. Moreover, its rising ambitions have an influence on plant growth: "with the fundamental force of their being they unceasingly thrust away from the earthly, and it is this thrust that determines the upward direction of a plant growth" (Steiner 1995 [1992]: 121). One may say that the quicksilver child, born from the roots of the flower, jumped up from the earth 
with the help of the good side of the gnome's character. Likewise, the Mercurius gnome possesses a double nature. In the Rosicrucian tradition he is believed to be evil only because the malevolent devil manipulates its "simple and benevolent feelings ... by the tempting offer of abundant riches, and the accomplishment of all their desires" (The Rosicrucian 1835: 42). The Rosicrucian adepts had to use every opportunity to teach the gnomes about the "nature of their own being, the raptures of eternal life in Heaven, and the malice of their deceitful neighbors, the imprisoned demons" (The Rosicrucian 1835: 141). The gnome in "The MoonFlower" is not only a deceitful lover who wants to marry the Moon Princess; he is also the merchant who supplies the moon people with gemstones. It has to be remembered that the spiritual city/New Jerusalem in the fin de siècle imagery was a city of jewels. It symbolises infinite earthly beauty which spreads the light across the darkness of the material world. The gnome who delivers the precious stones is connected with this hidden terrestrial treasure, but the red mole is just a blind, malicious force which has to be killed at the end of the tale by the falling shoe - this not only constitutes the Prince's heritage but also a Mercurial symbol. The red mole/gnome/quicksilver child trinity is a complex symbol of the transformative force.

The idea of small images of development enclosed in one character and described in several lines are typical of fairy tale traditions. Max Lüthi wrote that the beauty of the fairy tale is in its absolute clarity and precision (1976 [1970]: 78). It does not assault the intellect with psychology and a chain of unneeded details. Everything in the fairy tale is portrayed with a thick, prominent line. Nevertheless, one fairy tale formed in its rigid frame may reflect the entire universe: "The fairy tale depicts external events, but these events seem to become spiritualized and sublimated almost by themselves" (Lüthi 1976 [1970]: 125). In consequence, a fairy tale is a chain of images linked by inner action in order to depict the macrocosm in microcosmic portrayals. The Victorians used this feature of fairy tales to convey mystical feelings. Fantastic imagination became equal with mystic imagination. The latter, according to Theodule Ribot, is based on a tendency to capture the ideal in the sensual (Ribot 1906: 120). Fantastic imagination in the nineteenth century serves the same purpose: "Fantasy being the organ of the Godlike ... Man thereby, though based ... on the small Visible, does nevertheless extend down into the infinite deeps of the Invisible" (Carlyle 1831: 173). One of the best fairy tale writers in the late Victorian era, George MacDonald, states that fantasy writers are divinely inspired and can discover the unexpected truth in their own texts "for he was dealing all the time with things that came from thoughts beyond his own" (MacDonald 1976 [1890]: 166). These profound symbols are bottomless in meaning and can capture the essence of the world like the gnome/red mole/quicksilver child trinity captured spiritual evolution. Laurence Housman is one of the most ingenious Victorian fairy tale 
writers, who is capable of embracing the macrocosm in one symbol. His personal quality of attaching importance to the slightest detail was famous among his employers in the book illustrating business (Engen 1983: 67). In his fairy tales, every detail plays a significant role and leads the readers' imagination to the depth of tangled meanings. Every symbol may be conceived as a link in the chain of the plot or be considered as an independent figure reflecting Victorian religious imagination. The vast sea of meanings, cultural implications, and personal preferences are hidden beneath the fairy tale's objects, landscapes, and characters. This cluster of a pan-cultural absolute is typical of the imperialistic Victorian imagination, obsessed with comparative studies. Once entering this fascinating world, one cannot resist the beauty of this profound labyrinth. Housman not only tells the story of inner transformation, but he also opens the doors to the myriad stories which were told before him; he creates a net of countless possibilities; in his story he involves the entire cultural universe. To read "The Moon-Flower" is not only to understand the action but also to look deep into the hero's literary, artistic, and philosophical background. Great potential dwells in the small images of the Prince and the Moon Princess. Analysed as separate symbols, they reveal the world of Victorian imagination, fascinations, and ways of understanding.

One of the most famous painters in Victorian times, G. F. Watts, expressed the symbolic meaning of the moon's love to man in his Endymion. The circular, uroboros shape of the pose in which the lovers were captured suggests the infinite unification of the divine with the human world. The state of Endymion's consciousness, an endless sleep without death, reflects a different perception of those who are enlightened and united with the sacred. The moon traditionally represents the immaterial, infinite, and superior part of man's life. In Gnosticism "lunar consciousness" represents the inner knowledge of the sun (God), reflected in the soul (Stevens 1998: 136); in alchemical texts the moon helps to purify the body and leads to a state of innocence; in Swedenborg's philosophy the moon is the Lord for those in the spiritual kingdom (Swedenborg 2009 [1758]: 66). All these references explain why the spirit in "The Moon-Flower" is symbolised by the Moon Princess. Housman is not the only fairy tale writer who ascribes spiritual values to the Moon. In Joseph Jacobs' The Buried Moon (1894), the moon is the Divine Light imprisoned by evil forces lurking under a devilish bog. In George MacDonald's At the Back of the North Wind (1871), the moon is the sphere of dreams, imagination, and spiritual freedom. In 1885 Timothy Harley published the The Moon Lore (1885) - a collection and interpretation of folktales, customs, and rituals relating to the moon. Housman's imagination mirrors the Victorian fascination with the moon. The difference between him and many other Victorian writers is that he uses his symbols with the awareness of the cultural meanings involved in them. As mentioned above, the spirit in Victorian times 
was not entirely flawless. The moon has its dark side as well. Traditionally, it is responsible not only for spiritual transformation but also for mental sickness, sexual activity, and vital forces. The moon has a double character. Hence, the relation between the ethereal, beautiful, and ghostly Moon Princess and the red mole is not a coincidence. In alchemy the moon very often has an evil side and is affiliated with poisonous creatures such as the basilisk, scorpion, or toad (Jung 1970: 144). The moon's changeable character relates it to a snail, which hides in a shell, to a frog which disappears under water, or a bear which withdraws into a cave (Guiley 2006: 201). The well-known hare symbol of the moon also had a double meaning. The timid and innocent hare from the Buddhist story merged with the Christian symbol of lust. Housman's red mole combines all these traditionally implied features of the dark moon: it is a blind, sexual force which threatens to grab the roots of the soul and imprison it under the earth; it is the animal which withdraws to an unknown dark place and reappears suddenly like the cyclic phases of the moon. Moreover, the idea that the moon fuses good with evil is reflected in the symbolism of plants. The moon-flower's roots are deep underground, but the stems aim for heaven. The moon is believed to be responsible for plant growth, and it was often depicted as a plant itself. In alchemy one may find several moon-related plants: Lunatica, Lunaria, Berrissa (Jung 1970: 133); in the Rig Veda the moon is one with the intoxicating soma plant (Hopkins 2007 [1895]: 117). The duality of the moon's character, in general, renders Housman's Princess more prone to reflect on the material being of her other half. One may speculate if Housman, being aware of the moon's traditional depictions, did not try to convey the theory that the soul is not the only source of defilement. The Moon Princess' encounter with the gnome-mole could be the result by her own dark side and not the consequence of the influence of the indecisive Prince exerted over her.

The hidden references to the vast cultural inheritance tell the reader more about the Moon Princess. She is not a simple moon spirit trapped by a gnome. She reflects a cultural heritage in her double-sided character. As a spirit of the moon she is related to transcendence and darkness, as a Princess she is traditionally related to her "alter ego" - the Prince. The female/male double is typical in fairy tales. The Princess is the feminine element of the self; her wisdom is otherworldly, it comes from a kingdom above, and her love is based on emotions. Therefore, the Moon Princess does not insist on finding a way to escape; the presence of the Prince is sufficient relief for her. On the other hand, from the beginning the Prince attempts to think of a way to free his beloved; he represents the masculine side, human values, and action; his kingdom belongs to the world below, a world of logic and reason. J. C. Cooper accurately notices that princesses in fairy tales usually are placed "above" the world in towers or on other planets; the princes usually come from below, from the earthly kingdom: "This 
theme runs through the symbolism of marriage, in which conflict between the higher and lower is resolved by the performance of difficult tasks that raise the lower upwards and bring the higher down to a level at which union is possible" (Cooper 1983: 86). One might be slightly surprised that the one who brings reason, method, and a solution to the male/female unity is not depicted in the tale as a knight in shining armour with a kingly throne awaiting him. On the contrary, he is lost, laughed at, and has no kingdom: "His brothers laughed at him, and said: Our father was wise to play these old shoes off upon you! If it had been either of us we would have gone and bought ourselves an army and fought for a just share in the inheritance" (Housman 1895: 139). Instead of a knight, Housman creates a simpleton and in this way refers to the long tradition of holy fools. In the Russian Orthodox religion, Islamic culture, Irish tradition, and many others, holy or divine fools, duine le dia (a person with God), may be found. Those who are destined to reach the divine kingdom are silly, innocent, capable of accepting events as they come and cannot separate the natural from the supernatural. They have a broader, perspective; hence, are deprived of fear and sometimes common sense. They use their mind as often as they use their intuition. Housman's Prince is a perfect example of the folk simpleton. He is destined to gain a big kingdom, and he accepts his goal without hesitance. He is patient to wait for his destiny, and when the moment comes, he is not afraid to follow his intuitive wisdom. In nineteenthcentury theosophy, it was believed that intuition is the same for the soul as the senses for the body. The spirit transmits the transcendental truth by the organ of intuition: "The Intuition of the Soul is the most precious of our possessions. Those who have attained to Soul-Knowledge value the Gnosis above all mundane things" (Sinclair 1887: 520). When one of the Prince's shoes starts running, he follows it regardless the circumstances of being lost in a dense and unknown forest. The missing shoe in folklore means "the search for a mate and the desire to enter into new relations and assume a higher form of obligation than had heretofore existed" (Hunt 1997 [1939]: 114). The Prince is not afraid to go further and deeper, to knock onto a house door and enter its dark rooms. He is the one who releases the water from the well and prepares the gate to the other world. $\mathrm{He}$ is the one who has dreams. The latter is a minute detail of great importance. In the Victorian age, the one who has prophetic dreams was believed to be able to use spiritual perception. Carl du Prel compares dreams to Greek oracles; in the mystic path they are divine signs sent for those who are open to sacred knowledge (du Prel 1889: 52). The innocent Prince is predestined to be transformed into the moon-child; he can easily tear the mask of materiality, as he tore his clothes while he was running through the forest. The nakedness or tearing off the clothes as a symbol of old personality is very important in many initiation ceremonies. Housman's Prince left his former life before he had even met the Moon Princess; he was prepared to recognise her as his higher half. The transformation was his 
destiny. After the ascendance to the moon, he takes off his shoes which "is an act of consecration" (Hunt 1997 [1939]: 415). It symbolises an entrance to a holy place and transformation to a divine state.

Jenny Bourne Taylor, in her short outline of fin de siècle psychology, stressed the importance of the fast developing fascination in multi-personality, doubleness, and all mental reflections of the alter ego (Taylor 2007: 26). This multisided image of man raised the problem for Victorian religion in which clearly defined moral principles were addressed to the rational and "singleconscious" man. The complex fin the siècle mentality found a suitable field to express the different levels of cognition. Mysticism approved all planes of the structure of the human being and allowed them to unify in a mystic wholeness. In real life, the experience of unification was granted only to some people, but in fairy tales the mystic path could be trod by everyone. This popular genre reflected the most significant features of Victorian religious imagination: immanence, evolution, and symbolism. As Prickett emphasised in his book, most of Victorian fantasies are inner geographies (Prickett 1979: 34). Slusser and Rabkin in Mindscapes: The Geographies of Imagined Worlds consider fantasy as a product of a general human need to transform the Platonic "ghostly paradigms" to "solidly realised places" (Slusser \& Rabkin 1989: x). In Platonic philosophy reality is merely an illusion. True knowledge about the world does not depend on the interaction of our senses with external objects. Truth and the "actual reality" may be comprehended simply by the mind's recollection of forgotten knowledge (Nagy 1991: 37). Being a product of the mind, fantasy reveals the hidden ideal reality. From this point of view imagined worlds are more real than ordinary reality. This is the element of fairy tales which fascinated the Victorians. They believed to capture Kant's Idea in meaningful and complex symbols. Housman's intricate symbols open the doors of perception and let the reader look beyond the surface of appearance. Moreover, as the world is a "consistent story, fictive or actually historic" (Patmore 1893: 24), in which the same objects of imagination are shared between every human being, and the recurring themes are believed to be close to ideal reality. The vast amount of references involved in the simple story is not a consequence of over-sophistication. The Moon Princess, the Prince, and the trickster are typical Victorian symbols which in their deep nature reflect the world as a conglomerate of spiritual archetypes. The recognition of this superior world which underlines our poor reality is the aim of mystic fairy tales. The inner development of fairy tale characters from divided personalities to the consecrated self opens one's spiritual eyes and reveals the mystic harmony of the universe. "The Moon-Flower" transforms not only the self but also the world into a spiritual kingdom and gives the Victorian consciousness a proof of divine order in the world. Laurence Housman knew that the only way to experience the conviction of presence of the divine kingdom was to fictionalise it and allow 
imagination to participate in belief. His fairy tales, and "The Moon-Flower" in particular, reflect the Victorian deep need of certainty in a sacred sense of the world, the retold tales should trick the brain and change the dull reality into a miracle:

man having a peculiar human faculty for making himself believe in anything that he sets his mind on - any fixed ritual or observance, carried through day-in day-out, with a certain solemnity of mind, gets into the blood till something which cannot rightly be called knowledge becomes conviction; and it is for more out of conviction than out of genuine knowledge that the world has grown its religious beliefs - beliefs about things which in their very nature are impossible of proof. (Housman 1937: 144)

\section{REFERENCES}

\section{PRIMARY SOURCES}

Buckham, John W. 1915. Mysticism and modern life. New York, NY: The Abingdon Press.

Carlyle, Thomas. 1831. Sartor resartus. London: Chapman \& Hall, Ltd.

Curtis, Adela M. 1906. The new mysticism: Six lectures given in Kensington. London: Curtis \& Davison.

Grimm, Jacob \& Wilhelm K. Grimm. 2008 [1822]. The Spirit in the Glass Bottle. In The classical works of the Brothers Grimm, 137-156. Raleigh, NC: LuLu Press.

Harley, Timothy. 1885. Moon Lore. London: Swan Sonnenschein.

Housman, Laurence. 1895. The Moon-Flower. In Laurence Housman, House of Joy, 135-169. London: Kegan Paul, Trench Trübner \& Co.

Housman, Laurence. 1937. The unexpected years. London: Jonathan Cape.

Inge, William R. 1947. Mysticism in religion. London: Hutchinson's University Library.

Jackson, Holbrook. 1913. The eighteen nineties. London: Grant Richards.

Jacobs, Joseph. 1894. The Buried Moon. In More English Fairy Tales, 110-118. London \& New York: G. P. Putnam's Sons, The Knickerbocker Press.

MacDonald, George. 1871. At the Back of the North Wind. London: Strahan \& Co.

MacDonald, George. 1976 [1890]. The fantastic imagination. In Lance Salway (ed.), A peculiar gift. Nineteenth century writings on books of children, 162-167. Middlesex: Penguin Books.

Patmore, Coventry K.D. 1893. Religio poetae. London: G. Bell.

Prel, Carl du. 1889. The philosophy of mysticism (translated by C.C. Massey). London: George Redway.

Ribot, Theoudule A. 1906. Essay on the creative imagination (translated by Albert H. N. Baron). Chicago, IL: The Open Court Publishing Co.

Rosicrucian Philosophy, The. 1835. In The Knickerbocker; or New-York Monthly Magazine. Vol. $5,1835.35-43$.

Sinclair, Marie. 1887. The mystery of the ages. London: C.L.H. Wallace.

Spurgeon, Caroline F. E. 1913. Mysticism in English literature. Cambridge: Cambridge University 
Press.

Stanley Arthur P. 1879. Addresses and sermons delivered during a visit to United States and Canada in 1878. New York, NY: Macmillan.

Swedenborg, Emanuel. 2003 [1763]. Divine love and wisdom. (translated from the Latin by George F. Dole.) West Chester: Swedenborg Foundation.

Swedenborg, Emanuel. 2009 [1758]. Heaven and hell: Also the world of spirits or intermediate state from things heard and seen. West Chester: Swedenborg Foundation.

Steiner, Rudolf. 1995 [1992]. Nature spirits. Selected lectures (edited by Wolf-Ulrich Klünker). London: Rudolf Steiner Press.

Underhill, Evelyn. 1912. Mysticism: A study in the nature and development of man's spiritual consciousness. New York, NY: E. P. Dutton and Company.

Underhill, Evelyn. 1913. The mystic way; a psychological study in Christian origins. London: J.M. Dent \& Sons.

Wilson, Floyd B. 1908. The Discovery of the Soul: Out of Mysticism, Light and Progress. New York, NY: R.F. Fenno \& Company.

\section{SECONDARY SOURCES}

Campbell, Joseph. 1949. The hero with a thousand faces. Princeton, NJ: Princeton University Press.

Cicchetti, Jane. 2003. Dreams, symbols, and homeopathy: Archetypal dimensions of healing. Berkeley, CA: North Atlantic Books.

Cooper, Jean C. 1983. Fairy tales. Allegories of the inner life. Wellingborough, Northamptonshire: Aquarian Press.

Engen, Rodney K. 1983. Laurence Housman. Stroud: Catalpa Press.

Guiley, Rosemary A. 2006. The encyclopedia of magic and alchemy. New York, NY: Infobase Publishing.

Haeffner, Mark. 1994. Dictionary of alchemy. London: Aquarian Press.

Hasse, Donald (ed.). 2008. The Greenwood encyclopedia of folktales and fairy tales. Vol. 2. Westport, CT: Greenwood Press.

Hopkins, Edward W. 2007 [1895]. The religions of India. Fairford, Gloucestershire: Echo Library.

Hughes, Stuart H. 1958. Consciousness and society: The reorientation of European social thought, 1890-1930 . New York, NY: Vintage Books.

Hunt, Clyde H. 1997 [1939]. Masonic symbolism. Whitefish, MT: Kessinger Publishing.

Jung, Carl G. 1970. Mysterium Coniunctionis; An inquiry into the separation and synthesis of psychic opposites in alchemy (edited and translated by R.F.C. Hull.) (The Collected Works of C.G. Jung, vol. 14). Princeton, NJ: Princeton University Press.

Jung, Carl G. 2015 [1969]. The archetypes and the collective unconscious. (Edited by William McGuire and translated by R.F.C Hull.) (The Collected Works of C.G. Jung, vol. 9). New York, NY: Routledge \& Kegan Paul.

Lüthi, Max. 1976 [1970]. Once upon a time. On the nature of fairy tales (translated by Lee Chadeayne \& Paul Gottwald). Bloomington, IN: Indiana University Press.

Murray, Stein \& Corbett, Lionel (eds.). 1991. Psyche's stories. Modern Jungian interpretations of fairy tales. Vol. 1. Wilmette, IL: Chiron Publications.

Nagy, Marilyn. 1991. Philosophical issues in the psychology of C.G. Jung. Albany, NY: State University of New York Press. 
Oppenheim, Janet. 1985. The other world. Spiritualism and psychical research in England 1850 1914. Cambridge: Cambridge University Press.

Owen, Alex. 2004. The place of enchantment. British occultism and the culture of the modern. Chicago, IL: University of Chicago Press.

Prickett, Stephen. 1979. Victorian fantasy. Hassocks, Sussex: The Harvester Press.

Rooney, Anne. 1993. Hunting in Middle English literature. Woodbridge, Suffolk: D.S. Brewer \& Boydell Press.

Sander, David. 1996. The fantastic sublime. Romanticism and transcendence in nineteenth-century children's fantasy literature. Westport, CT: Greenwood Press.

Silberer, Herbert. 2003 [1917]. Problems of mysticism and its symbolism (translated by Smith E. Jelliffe). Whitefish, MT: Kessinger Publishing.

Slusser, George E. \& Eric S. Rabkin. 1989. Introduction: The concept of mindscape. In George E. Slusser \& Eric S. Rabkin (eds), Mindscapes: The geographies of imagined worlds, ixxiii. Carbondale \& Edwardsville, IL: Southern Illinois University Press.

Stevens, Anthony. 1998. Ariadne's clue. A guide to the symbols of humankind. London: Allen Lane $\&$ The Penguin Press.

Taylor, Jenny Bourne 2007. Psychology at the fin de siècle. In Gail Marshall (ed.), The Cambridge companion to fin de siècle, 13-30. Cambridge: Cambridge University Press.

Zimmer, Hinnrich R. 1993 [1948]. The king and the corpse: Tales of the soul's conquest of evil. (Edited by Joseph Campbell.) Princeton, NJ: Princeton University Press.

Zipes, Jack. 1989. Preface. In Jack Zipes (ed.), Victorian fairy tales. The revolt of the fairies and elves, xiii-xxix. New York, NY: Routledge. 